\title{
Identification and Colonization of Endophytic Fungi from Soybean (Glycine max (L.) Merril) under Different Environmental Conditions
}

\author{
Ida Chapaval Pimentel $^{*}$, Chirlei Glienke-Blanco ${ }^{2}$, Juarez Gabardo $^{2}$, Rodrigo Makowiecky \\ Stuart $^{3}$ and João Lúcio Azevedo ${ }^{4}$ \\ ${ }^{1}$ Departamento de Patologia Básica; ida@ufpr.br; ${ }^{2}$ Departamento de Genética; Setor de Ciências Biológicas; \\ Universidade Federal do Paraná, C. P. 19031; 81531-990; Curitiba - PR - Brasil. ${ }^{3}$ Departamento de Genética; \\ Escola Superior de Agricultura "Luiz de Queiroz";USP; Piracicaba - SP - Brasil. ${ }^{4}$ Núcleo Integrado de \\ Biotecnologia; Universidade de Mogi das Cruzes; Mogi das Cruzes - SP - Brasil
}

\begin{abstract}
A total of 297 endophytic fungi were isolated from 1728 leaf and stem fragments collected about twenty and forty days after germination from soybean (Glycine max (L.) Merril) plants grown in the field and a greenhouse. The fungi belonged to eight groups, six dematiaceous genera (Alternaria, Cladosporium, Chaetomium, Curvularia, Drechslera and Scopulariopsis) and the non-dematiaceous genera Acremonium, Aspergillus, Colletotrichum, $\underline{\text { Fusarium, }}$ Paecilomyces and Penicillium along with some Mycelia sterilia.. There were qualitative and quantitative differences in the type and number of isolates obtained from greenhouse and field-grown plants, with more isolates being obtained from the latter. No difference was found in the number of fungi isolated from leaves and stems irrespective of where the plants was grown. For was field-grown plants, the number of isolates decreased as the plants aged and more fungi were found in tissues near the soil, while for greenhouse-grown plants the number of isolates increased as the plants aged but in this case no more fungi were isolated from those tissues nearer the soil. These results could have biotechnological relevance for the biological control of pests or plant growth promotion.
\end{abstract}

Key words: Endophytic fungi, Soybean, Biological control

\section{INTRODUCTION}

Soybean (Glycine $\max (\mathrm{L}$.$) Merril) is an Asiatic$ leguminous plant cultivated in several parts of the world for its oil and protein, which are extensively used in the manufacture of animal and human foodstuffs. In terms of cultivated area and productivity, soybean is the major crop cultivated in Brazil and is of extreme economic importance for the state of Paraná, which is one of the main Brazilian soybean-growing regions producing soybeans for export (Robbs and Bittencourt
(1998). Soybean monoculture can sometimes cause environmental problems and also favors the explosive growth of pest populations whose action is responsible for grain losses of about 30\%, soybean being susceptible insect attack during all of its growth cycle.

The chemical insecticides which have been used in crops since the 1940's have, in many cases, proved to be efficient at controlling insect pests, although they could also affect nontarget organisms (Smith and Stratton, 1986). The same is true for fungicides and herbicides meant to control

\footnotetext{
${ }^{*}$ Author for correspondence
} 
phytopathogenic fungi and weeds respectively, but which also have the capacity to inhibit the growth and multiplication of beneficial microorganisms, including endophytic bacteria and fungi, which perform crucial environmental roles. In fact, soybean plants treated with glyphosate herbicide show differences in endophytic bacteria composition when compared to bacterial communities isolated from plants without glyphosate treatment (Kuklinsky-Sobral et al., 2005). Some of these bacteria affected by glyphosate applications can be important plant growth promoters by producing auxin and fixing nitrogen (Kuklinsky-Sobral et al., 2004).

Endophytic microorganisms live within host plants without causing any noticeable symptoms of disease (Carroll, 1988; Azevedo, 1998; Pinto et al., 2000). It is hypothesized that the endophytes, in contrast to known pathogens, generally have far greater phenotypic plasticity and thus more options to interact with their host than pathogens (Shultz and Boyle, 2005). Since the 1970's several reports have shown that these endophytes have important roles in protecting their host against predators and pathogens. Reports of endophytic microorganisms protecting their plant host against insects are quite common Azevedo et al.,. (2000), but there are relatively few studies on soybean microbiota and with few exceptions, have been the researches reported carried out in temperate regions where agricultural problems related to pests and diseases are not so pressing.

This work in this paper was carried out to isolate endophytic fungi from soybean plants growing in the field and in a greenhouse to identify them and to search for isolates that could be of interest in the control of agricultural pests.

\section{MATERIALS AND METHODS}

\section{Sample collection}

During early November 1998 soybean, Glycine $\max$ (L.) Merril cultivar-202-COODETEC (Cooperativa Central Agropecuária de Desenvolvimento Tecnológico e Econômico Ltda Cascavel, Paraná, Brazil), seeds were planted in a Gleissoil in a field at Cangüiri Experimental Station (Division of Agrarian Sciences, Federal University of Paraná (UFPR), Brazil) and in pots containing the same soil in a greenhouse at the Biochemistry Department, Biological Sciences Sector, UFPR. Seeds did not receive any treatment with agrochemicals either before or after planting. The climate in the region is humid mesothermic with an average annual precipitation of $1400 \mathrm{~mm}$, concentrated mainly in January and February. The average temperature during the experiment was $17.6^{\circ} \mathrm{C}$ in the field and $26^{\circ} \mathrm{C}$ in the greenhouse.

From mid November 1998 through March 1999, leaf and stem samples were collected about 20 days after germination during the V3 vegetative stage when the principal stem had three nodes (as counted from the interfoliar node, these plants being designated V3 plants) and about 40 days after germination during the $\mathrm{R} 2$ reproductive stage when there was a flower in the penultimate node of the apex and a completely uncurled leaf (R2 plants) (Fehret et al., 1971). A total of 36 healthy field- or greenhouse-grown plants were randomly sampled, nine each of $\mathrm{V} 3$ and $\mathrm{R} 2$ field-grown plants (coded V3F and R2F) and nine each of V3 and R2 greenhouse-grown plants (coded V3G and R2G). Leaf and stem samples taken from soil level until just below the insertion of the 1st superior pair of leaves were classed as 'low' (L) and those from above the 1st pair of leaves as 'high' $(\mathrm{H})$. All samples were processed immediately after collection.

\section{Isolation of endophytic fungi}

Endophytic fungi were isolated according the protocols described by Petrini (1986), which were slightly modified based on preliminary tests. All leaf and stem samples were washed twice in distilled water then surface sterilized by immersion for 1 minute in $70 \%(\mathrm{v} / \mathrm{v})$ ethanol, 4 minutes in sodium hypochlorite $(3 \% \quad(\mathrm{v} / \mathrm{v})$ available chlorine) and 30 seconds in $70 \%(\mathrm{v} / \mathrm{v})$ ethanol and then washed three times in sterilized distilled water for 1 minute each time. After surface sterilization, the samples were cut into 5-7 $\mathrm{mm}$ pieces and aseptically transferred to plates containing potato dextrose agar (PDA, $\mathrm{pH}$ 6.8, containing (g/l): potato 200; dextrose 20; agar 15.), which had been autoclaved for 15 minutes at $121^{\circ} \mathrm{C}$ and then aseptically supplemented with 100 $\mu \mathrm{g} / \mathrm{ml}$ of terramycin (Pfizer) to suppress bacterial growth. Aliquots from the third wash were plated onto PDA to check that surface sterilization had been effective. A total of 1728 fragments were plated, 48 from each of the 36 plants investigated. To facilitate isolation of slow-growing and lowsporulating fungi, half of the plates were incubated at $28^{\circ} \mathrm{C}$ and the other half at $37^{\circ} \mathrm{C}$. The plates were checked each day for up to thirty days after 
inoculation and any fungi present was isolated, purified and then maintained at $4^{\circ} \mathrm{C}$ on PDA slopes for further identification. Percentage colonization was defined as the total number of fragments colonized by fungi in relation to the total number of fragments x 100 (Carroll and Carroll, 1978). The isolates were identified by growing them on PDA plates or in micro-culture (Kern and Blevins, 1999) and examining the colonies for asexual or sexual reproductive structures using optical and scanning electron microscopy (SEM) and taxonomic keys (Ellis, 1971, 1976; Barnett and Hunter 1972; Arx, 1974; Petrini, 1986; Rossman et al., 1987; Alves, 1998).

\section{Statistical analysis}

Results were analyzed using a completely randomized analysis of variance (anova, $\mathrm{p}<0.05$ ) for unequally replicated treatments (pimentelgomes, 1985) and the tukey test $(\mathrm{p}<0.05)$ for comparison of means.

\section{RESULTS AND DISCUSSION}

\section{Types of fungi isolated}

A total of 297 endophytic fungi were isolated from the 1728 leaf and stem fragments analyzed giving a percentage colonization rate of $17.2 \%, 231$ isolates being obtained from the field-grown plants and 66 from the greenhouse-grown plants (Table 1). Fig. 1 showed that dematiaceous fungi were most frequently isolated from field-grown plants, but for greenhouse-grown plants there were no statistical differences between the number of isolates obtained from the most frequently isolated groups (dematiaceous fungi, Aspergillus, Fusarium, Penicillium and Mycelia sterilia). Isolates were obtained from eight fungal groups: six dematiaceous genera (Alternaria, Cladosporium, Chaetomium, Curvularia, Drechslera and Scopulariopsis) and the nondematiaceous genera Acremonium, Aspergillus, Colletotrichum, Fusarium, Paecilomyces and Penicillium along with some Mycelia sterilia (Fig. 1). Most of the isolates were obtained at $28^{\circ} \mathrm{C}$, the exception being the Mycelia sterilia, which was at $37^{\circ} \mathrm{C}$.

Table 1 - Number of isolates of endophytic fungi obtained from soybean leaf and stem fragments

\begin{tabular}{|c|c|c|c|c|c|}
\hline Growth environment & Organ & $\begin{array}{c}\text { Height above } \\
\text { ground }\end{array}$ & $\begin{array}{c}\text { Number of } \\
\text { isolates }\end{array}$ & $\begin{array}{l}\text { Colonization } \\
\text { rate }(\%)\end{array}$ & $\begin{array}{c}\text { Total number of } \\
\text { isolates by organ } \\
\text { (Low + Hight) }\end{array}$ \\
\hline \multirow[t]{2}{*}{ Field-grown plants } & Leaf & $\begin{array}{l}\text { Low } \\
\text { High }\end{array}$ & $\begin{array}{l}75 \\
43\end{array}$ & $\begin{array}{l}34.7 \\
19.9\end{array}$ & Leaf $=118$ \\
\hline & Stem & $\begin{array}{l}\text { Low } \\
\text { High }\end{array}$ & $\begin{array}{l}69 \\
44\end{array}$ & $\begin{array}{l}31.9 \\
20.4\end{array}$ & Stem $=113$ \\
\hline $\begin{array}{l}\text { Total isolates from field- } \\
\text { grown plants }\end{array}$ & & & 231 & 26.7 & \\
\hline \multirow[t]{2}{*}{ Greenhouse-grown plants } & Leaf & $\begin{array}{l}\text { Low } \\
\text { High }\end{array}$ & $\begin{array}{l}16 \\
18\end{array}$ & $\begin{array}{l}7.4 \\
8.3\end{array}$ & Leaf $=34$ \\
\hline & Stem & $\begin{array}{l}\text { Low } \\
\text { High }\end{array}$ & $\begin{array}{l}14 \\
18\end{array}$ & $\begin{array}{l}6.5 \\
8.3\end{array}$ & Stem $=32$ \\
\hline $\begin{array}{l}\text { Total isolates from } \\
\text { greenhouse-grown plants }\end{array}$ & & & 66 & 7.6 & \\
\hline Total number of isolates & & & 297 & 17.2 & 297 \\
\hline
\end{tabular}




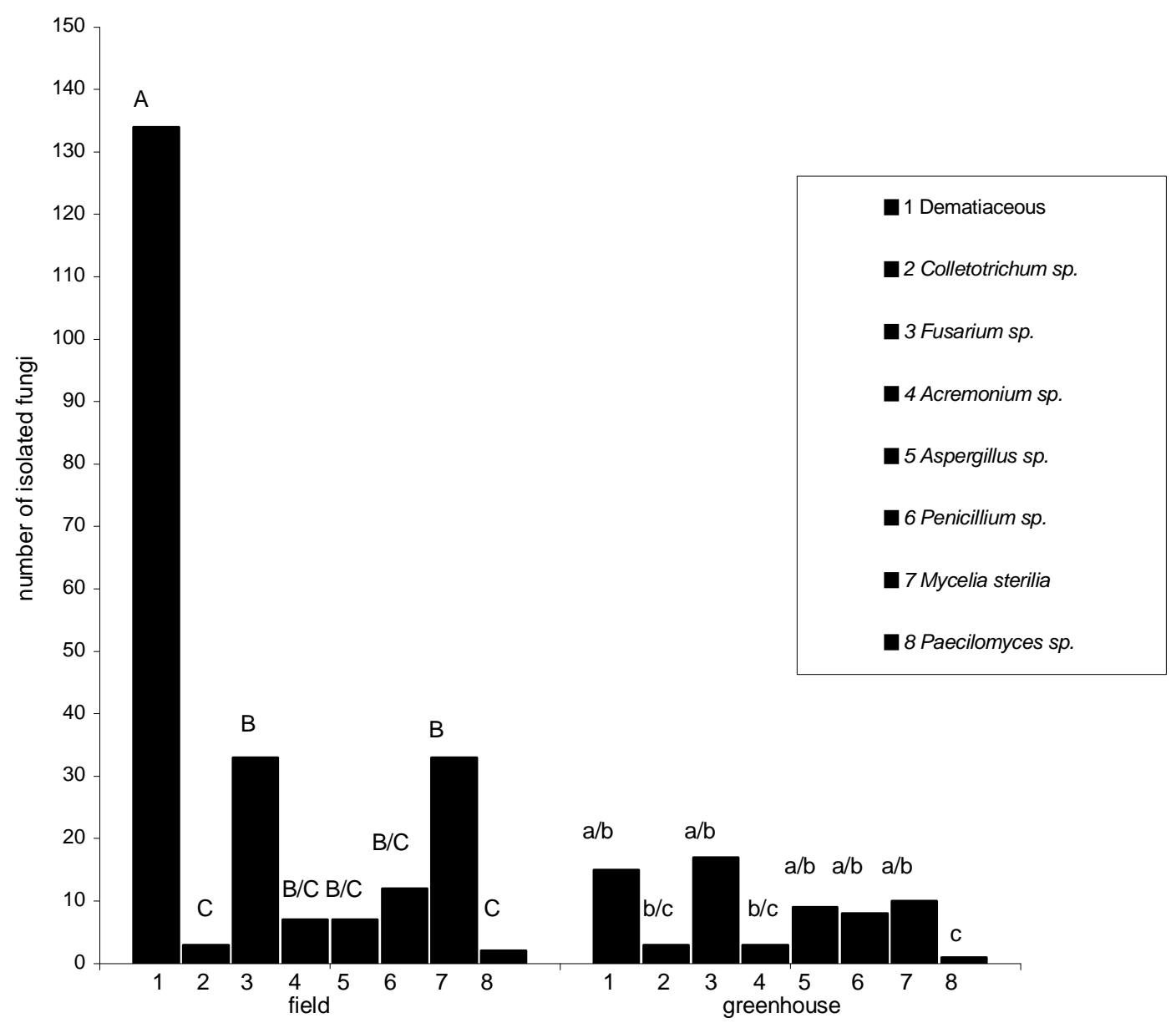

Figure 1 - Number of endophytic fungi isolated from the leaves and stems of soybean grown in the field and in a greenhouse. 1) dematiaceous fungi; 2) Colletotrichum; 3) Fusarium; 4) Acremonium; 5) Aspergillus; 6) Penicillium; 7) Mycelia sterilia; 8) Paecilomyces. Identical upper (field-grown plants) and lower case (greenhouse-grown plants) indicate that there were no statistically significant differences between the groups (Tukey test, $\mathrm{P}<0.05$ ).

Results supported the work of Miller and Roy (1982), who also isolated Alternaria, Aspergillus, Cladosporium, Colletotrichum, Fusarium, Paecilomyces and Penicillium from soybean leaves and seeds. The genera Paecilomyces and Cladosporium have also been found in barley and other plants (Schultz et al., 1998) and known to contain entomopathogenic species with potential for use in the biocontrol of insect pests (Robbs and Bittencourt, 1998; Alves, 1998). Acremonium, a genus known to have effects on insects and other herbivores was also isolated (Breen, 1994; Azevedo et al., 2000), and Aspergillus, a genus containing species that could be used in insect control, although some species contain aflatoxins and other undesirable compounds.
Soybean plants are susceptible to Colletotrichum (a genus known to cause antracnose), during all stages of development, with typical symptoms appearing during the R1 stage at the beginning of the reproductive stage (Sinclair, 1991), the primary source of Colletotrichum infection being infected seeds, residual plant material and infected alternative hosts (Sinclair and Backman, 1989; Sinclair, 1991). Colletotrichum was isolated from apparently healthy field and greenhouse-grown soybean plants, which could have been because sampling period was too short to allow symptoms of antracnose to be manifested (although no symptoms were observed in even older plants) or that the isolates were non-pathogenic. Another alternative was that Colletotrichum were indeed 
pathogenic but the complex system of endophytes inside the plants prevented antracnose. Endophytic Colletotrichum isolates have already been described in soybean (Miller and Roy, 1982; Hartman et al., 1986), while Freeman and Rodrigues (1993) have reported that in Colletotrichum endophytic and pathogenic strains could be obtained from each other by a single mutational event.

\section{Effect of plant age on the number of isolates}

Dematiaceous fungi were the principal isolates obtained from the V3 and R2 stage plants grown under both field and greenhouse conditions It was found that the number of isolates obtained from field-grown plants decreased with increasing age of the plants, with 137 isolates being obtained from young V3 plants and 94 isolates from the more mature R3 plants. This could have been due to a lack of essential nutrients, as was observed for endophytic bacteria by McInroy and Kloeper (1995) who showed that some of the essential nutrients needed by such bacteria were unavailable during the maturation and senescence of plants. For greenhouse-grown plants, however, it was found that the number of endophytic fungal isolates increased as the plants aged, with only 11 isolates being obtained from V3 plants and 55 from R2 plants. This increase could be accounted by the fact that the average temperature in greenhouse experiments was $26^{\circ} \mathrm{C}$ as compared to about $18^{\circ} \mathrm{C}$ in the field and conditions dryer in the greenhouse as compared to the comparatively wet field conditions. The incidence of endophytic fungi in soybean has been shown to be related to several factors, including the developmental stage during which the plant is sampled (Miller and Roy 1982), environmental conditions (Elamo et al., 1999) and the location of the plant and the age of the leaves (Arnold and Herre, 2003) An increase in endophytic mycobiota from young to mature plants has also been shown for several endophytic populations, including populations of Stylosanthes species (Pereira et al., 1993; Rodrigues, 1994).

\section{Effect of isolation site on the number of isolates}

No differences between the number of fungal isolates obtained from the stems (113 isolates) and leaves (118 isolates) of field-grown plants and greenhouse-grown plants was found where 32 isolates were obtained from stems as compared to 34 from leaves (Table 1). For greenhouse-grown plants the height above soil-level at which the samples were taken did not appear to influence the number of isolates obtained from either the leaves or stems of the plants sampled, whereas for fieldgrown plants, more isolates were obtained from samples taken nearer the ground ('low' samples) than from samples taken further away from the soil ('high' samples). These differences could be due to infection in the field occurring mainly via the roots while under greenhouse conditions, infection occurred via the stomata. Fisher et al., (1992) observed that parts of maize-stems nearer the soil showed a lower incidence of fungal infection and explained this as probably being due to these parts of the stem having an increased frequency of bacteria, which inhibited fungal colonization, although with variable frequencies,

Five fungal groups (dematiaceous fungi, Fusarium. Aspergillus, Penicillium and Mycelia sterilia), were isolated at variable frequencies from the leaves and stems of both the field-grown and greenhouse-grown plants. However, while Colletotrichum was isolated from both the stems and leaves of greenhouse-grown plants in the case of field-grown plants, it was only isolated from the higher leaves. In addition, although Acremonium was isolated from both the stems and the lower (but not the higher) leaves of field-grown plants not isolated at all from the leaves of greenhousegrown plants, while Paecilomyces was isolated only from the leaves of both field-grown and greenhouse-grown plants.

It thus seemed that organs and parts of soybean plants were preferentally occupied by different groups of fungal isolates, something which has also been seen in maize where more fungal species were isolated from stems than from leaves (Fisher et al. 1992). Present results would lead to a better understanding of the processes by which endophytic fungi entered soybean plants, and also be of value when microorganisms that promoted better plant growth, nitrogen fixation or protection against pests were deliberately introduced into plants. Research on endophytic fungi is a new and exciting avenue for biotechnology, opening the possibility of discovering ways of economically using fungal species for both biological control and plant growth promotion.

\section{RESUMO}

A partir de 1728 fragmentos de hastes e folhas de soja (Glycine $\max (\mathrm{L}$.$) Merril). provenientes de$ 
plantas do campo e de casa de vegetação, coletadas cerca de 20 e 40 dias após a germinação das sementes, 297 fungos endofíticos foram isolados. Os gêneros encontrados foram: Alternaria, Cladosporium, Curvularia, Chaetomium, Scopulariopsis, Drechslera (todos dematiáceos) além de Colletotrichum, Fusarium, Acremonium, Aspergillus, Penicillium, Paecilomyces e Mycelia sterilia. Foram detectadas diferenças qualitativas e quantitativas entre os isolados, em relação a micobiota de hospedeiros provenientes do campo e de casa de vegetação com maior frequência de fungos isolados de plantas no campo em comparação com as de casa de vegetação. Houve diminuição da frequência de fungos com a idade das plantas crescidas no campo, ocorrendo o inverso com as da casa de vegetação, mas em ambos os casos, não houve diferença no número de fungos isolados de hastes e de folhas. Houve em plantas crescidas no campo uma maior incidência nas regiões próximas ao solo o que não ocorreu nas plantas provenientes da casa de vegetação. Os resultados podem ser de utilidade do ponto de vista biotecnológico pelo uso de endófitos introduzidos deliberadamente em plantas visando o controle biológico de pestes ou promoção de crescimento vegetal.

\section{REFERENCES}

Alves, S. B. (1998), Controle microbiano de insetos. Piracicaba: Fundação de Estudos Agrários Luiz de Queiroz. pp. 1163.

Arnold, A. E. and Herre, E. A. (2003), Canopy cover and leaf age affect colonization by tropical fungal endophytes: ecological pattern and process in Theobroma cacao (Malvaceae). Mycologia, 95, 388-398.

Arx, J. A. Von. (1974), The Genera of fungi sporulation in pure culture. $2^{\text {nd }}$ ed. Vaduz: J. Cramer. pp. 351.

Azevedo, J. L. (1998), Microrganismos endofíticos. In: Melo, I. S. and Azevedo, J. L. (Eds.). Ecologia microbiana. Jaguariúna: Embrapa Meio Ambiente. pp. 117-137.

Azevedo, J. L.; Macheroni Jr., W; Pereira, J. O. and Araújo, W. L. (2000), Endophytic microorganisms: a review on insect control and recent advances on tropical plants. Eletronic Journal of Biotechnology, 3, 01-36.

Barnett, H. C. and Hunter, B. B. (1972), Illustrated genera of imperfect fungi. 3. ed. Mineapolis: Burgess. pp. 241.
Breen, J. P. (1994), Acremonium endophyte interactions with enhanced plant resistance to insects. Annual Review of Entomology, 31, 401-423.

Carroll, G. C. (1988), Fungal endophytes in stems and leaves: from latent pathogen to mutualistic symbiont. Ecology, 69, 2-9.

Carroll, G. C. and Carroll, F. (1978), Studies on the incidence of coniferous endophytes in the Pacific Northwest. Canadian Journal of Botany, 5, 3034-3043.

Elamo, P.; Helander, M. L.; Saloniein, I. and Neuvonen, S. (1999), Birch family and environmental conditions affect endophytic fungi in leaves. Oecologia, 118, 151-156.

Ellis, M. B. (1971), Dematiaceous hyphomycetes. Surrey. Commonwealth Mycological Institute. pp. 608.

Ellis, M. B. (1976), More dematiaceous hyphomycetes. Surrey, Commonwealth Mycological Institute. pp. 507.

Fehret, W. R.; Caviness, C. E.; Burmood, D. T. and Pennington, J. S. (1971), Stage of development descriptions for soybeans, Glycine $\max$ (L.) Merril. Crop Science, 11, 929-930.

Fisher, P. J.; Petrini, O. and Lappin-Scott, M. (1992), The distribution of some fungal and bacterial endophytes in maize (Zea mays L.) New Phytologist, 122, 299-305.

Freeman, S. and Rodrigues, R. J. (1993), Genetic conversion of a fungal plant pathogen to a nonpathogenic, endophytic mutualist. Science, 260, 75-78.

Hartman, G. L.; Manandhar, J. B. and Sinclair, J. B. (1986), Incidence of Colletotrichum spp. on soybean and weeds in Illinois and pathogenicity of Colletotrichum truncatum. Plant Disease, 70, 780-782.

Kuklinsky-Sobral, J.; Araújo, W. L.; Mendes, R.; Gerardi, I. O.; Pizzirani-Kleiner, A. P. and Azevedo, J. L. (2004), Isolation and characterization of soybean-associated bacteria and their potential for plant growth promotion. Environmental Microbiology, 6, 1244-1251.

Kuklinsky-Sobral, J.; Araújo, W. L.; Mendes, R.; Gerardi, I. O.; Pizzirani-Kleiner, A. P. and Azevedo, J. L. (2005), Isolation and characterization of endophytic bacteria from soybean (Glycine max) grown in soil treated with glyphosate herbicide. Plant and Soil, 237, 91-99.

Kern, M. E. and Blevins, K. S. (1999), Micologia Médica. 2. ed. São Paulo: Premier. pp. 256.

McInroy, J. A. and Kloepper, J. W. (1995), Survey of indigenous bacterial endophytes from cotton and sweet corn. Plant and Soil, 173, 337-342.

Miller, W. A. and Roy, K. W. (1982), Mycoflora of soybean leaves, pods, and seeds in Mississipi. Canadian Journal of Botany, 60, 2716-2723.

Pereira, J. O; Azevedo, J. L. and Petrini, O. (1993), Endophytic fungi of Stylosanthes: a preliminary study. Mycologia, 85, 362-364. 
Petrini, O. (1986), Taxonomy of endophytic fungi of aerial plant tissues. In: Fokkema, N. J.; Heuvel, J. Van Den (Eds.). Microbiology of the Phyllosphere. Cambridge: University Press, pp. 175-87.

Pimentel Gomes, F. (1985),Curso de estatística experimental. São Paulo: Nobel. pp. 466.

Pinto, L. S. R. C.; Azevedo, J. L.; Pereira, J. O.; Vieira, M. L. C. and Labate, C. A. (2000), Symptomless infection of banana and maize by endophytic fungi impairs photosynthetic efficiency. New Phytologist 147, 609-615.

Robbs, C. F. and Bittencourt, A. M. (1998), Controle biológico de insetos. O controle biológico de insetos nocivos a agricultura com o emprego de fungos imperfeitos ou hifomicetos. Biotecnologia, Ciência e Desenvolvimento, 2, 10-12.

Rodrigues, K. F. (1994), The foliar fungal endophytes of the amazon palm Euterpe oleracea. Mycologia, 86, 376-385.

Rossman, A. Y.; Palm, M. E. and Spielman, L. J. (1987), A literature guide for the identification of plant pathogenic fungi. St Paul: APS Press. pp. 252.

Schultz, B.; Guske, S.; Damann, U. and Boyle, E. (1998), Endophyte-host-interaction II Defining symbiosis of the endophyte-host interaction. Synbiosis, 25, 213-227.

Schultz, B. and Boyle, C. (2005), The endophytic continuum. Mycological Research, 109, 661-686.

Sinclair, J. B. (1991), Latent infection of soybean plants and seeds by fungi. Plant Disease, 75, 220-224.

Sinclair, J. B. and Backman, P. A .(1989), Compendium of Soybean Disease. $3^{\text {rd }}$ ed. St. Paul: American Phytopathology Society. pp. 106.

Smith, T. M. and Stratton, G. W. (1986), Effects of synthetic pyrethroid insecticides on nontarget organisms. Residue Reviews, 97, 93-120. 